\title{
KEARIFAN SUFISME DALAM ISLAMISASI JAWA
}

\author{
Purwadi \\ Universitas Negeri Yogyakarta \\ Jl. Colombo Karang Malang (+62-274) 586168 Yogyakarta 55281 \\ E-mail: swastimay08@yahoo.com \\ HP. +62-81578865170
}

\begin{abstract}
This article shows the wisdom of Sufism on social transformation in Java at the early spread of Islam. Sufism approach tends to emphasize on self-awareness while accommodating ornamental outer symbols. This pattern makes the process of being Muslims in Java more peaceful and acceptable for those who already have certain believe and religion (animism, Hinduism and Buddhism).
\end{abstract}

Abstrak: Artikel ini menunjukkan kearifan Sufisme dalam melakukan transformasi sosial di Jawa pada awal penyebaran Islam. Pendekatan Sufisme cenderung menekankan pada perubahan kesadaran dalam diri sembari mengakomodasi simbol-simbol ornamen aspek luar. Pola ini menjadikan Islamisasi di Jawa cenderung lebih damai dan dapat diterima oleh masyarakat yang telah memiliki keyakinan dan agama lokal (animisme, Hindu, dan Buddha).

Kata Kunci: Islam, transformasi sosial, simbol, Sufisme, Jawa.

\section{A. Pendahuluan}

Agama Islam sudah berada di Jawa pada abad XV berdasarkan batu nisan dari makam Maulana Malik Ibrahim yang meninggal pada tahun 1419. Beliau adalah seorang kaya berkebangsaan Persia yang bergerak di bidang perdagangan rempah-rempah. Maulana Malik Ibrahim adalah salah seorang di antara wali sembilan yang dianggap penyebar Islam di pulau Jawa. Makamnya selalu dikunjungi oleh masyarakat luas sebagai apresiasi mereka terhadap kepeloporannya sebagai penyebar Islam serta keberadaannya sebagai wali yang biasanya dianggap memiliki daya linuwih (Jamil, 2000: 13).

Kebijaksanaan dari para mubaligh Islam yang datang ke Jawa dan mereka memahami watak dan kepribadian manusia Jawa. Sifat toleransi dari manusia 
Jawa sendiri yang mudah menerima setiap yang datang dari luar dan dianggap baik lalu disesuaikan dengan prinsip dan kebudayaan sendiri. Penyebaran Islam di Jawa banyak melalui ajaran-ajaran mistik. Dengan jalan perkawinan antar bangsawan, dan para pemeluk Islam giat memberikan contoh tauladan kepada masyarakat sehingga mudah meraih pengikut dan memudahkan Islam tersiar secara damai (Salam, 1977: 32).

Pada masa ini penyebaran Islam diprakarsai oleh Kasultanan Demak Bintoro. Segala daya upaya, pikiran demi dakwah Islamiyah. Sunan Giri yang waktu itu sedang menulis dengan kalam mencipta kalam atau penanya tadi menjadi Keris Kalamunyeng (Kamajaya, 1992: 4). Penyebaran Islam dengan berbasis kebudayaan daerah dan kearifan lokal kini telah mengakar di segala penjuru pulau Jawa.

\section{B. Membumikan Islam di JaWA}

Walisongo mempelopori dakwah Islam di bumi Jawa. Walisongo dianggap sebagai tokoh-tokoh sejarah kharismatik yang membumikan Islam di tanah yang sebelumnya berkembang bersama tradisi Hindu-Buddha (Salam, 1977: 56). Tradisi paling terkenal tentang persoalan sejarah Jawa dan perkembangan Islam adalah Babad Tanah Jawi. Babad tersebut menguraikan peranan penting para wali di bawah konsolidasi Demak dalam meratakan ajaran Islam di berbagai daerah yang masing-masing masih terikat di bawah kekuasaan bupatibupati daerah.

Para wali tersebut memiliki otoritas temporal dan spiritual yang sangat kuat. Berbagai cerita legendaris yang mengitari tokoh-tokoh ilahi ini memberi gambaran yang akurat bahwa pada tahun-tahun awal perkembangan Islam bersifat mistis, tidak ortodoks menurut standar saat ini dan mungkin di beberapa daerah tidak jauh berbeda dengan praktik-praktik Hindu Buddha. Kepercayaan pra Islam masih menjadi "konvensi" yang lestari hingga saat ini (Geertz, 1960: 17). Dakwah Islam ditinjau dari segi interaksinya dengan lingkungan sosial setempat berkembang dua tipe, yakni kompromis dan nonkompromis (Simuh, 1995). Dua pendekatan ini memiliki keistimewaan dan kelemahan sendiri-sendiri. Dasar pendekatan non-kompromis adalah pengembangan penalaran yang membedakan secara diametrik antara yang Islami dan tidak Islami. Istilah yang diametrik seperti ìmān dan kāfir, tawhīd dan musyrik, Isläm dan jahiliyah adalah sarana untuk menarik garis pemisah yang tegas dan jelas antara agama Islam dan tradisi yang berlawanan dengan Islam (Ricklefs, 1974: 5). Pendekatan non-kompromis memiliki ciri khusus hanya dapat menerima unsur yang seirama dan bisa diintegrasikan dengan agama Islam. 
Jati diri atau kepribadian ajaran agama dijaga dan harus dominan tidak akan dikorbankan. Apabila para pendukung mempertahankan budaya lama, tidak toleran dan bersifat agresif biasanya memancing ketegangan dan menimbulkan konflik (Gonda, 1975:54). Dalam sejarah penyebaran agama Islam keluar dari jazirah Arab, pendekatan kompromis paling dominan dan amat mewarnai, baik di Afrika, Eropa maupun Asia khususnya di kepulauan Nusantara. Meskipun Islam datang ke kepulauan Nusantara, termasuk relatif lebih lambat daripada kawasan-kawasan lain, tetapi dengan tanpa goncangan yang berarti agama tersebut dapat diterima dengan baik oleh penduduknya. Dengan demikian, negeri ini dihuni komunitas muslim terbesar bila dibandingkan negara-negara Islam lainnya yang lebih dahulu menerima Islam dan berlokasi lebih dekat dengan sumber Islam, yaitu Mekah dan Madinah.

Dari istilah kompromis ini, berarti Islam memadukan atau mempertemukan ajarannya dengan tradisi budaya setempat yang mungkin sebagian berlawanan dengan ajaran Islam yang tercantum dalam al-Qur'an. Pendekatan baru ini membentuk suatu sinkretis yang kadang kala menyimpang dari ajaran yang asli. Pendekatan dakwah kompromis telah berlalunya sejak pemerintahan khulafá' al-rasyídin (Simuh: 1995). Ada dua hal yang perlu dicatat sehubungan dengan adanya Islamisasi di Jawa. Agama Hindu, Buddha, dan kepercayaan lama telah berkembang lebih dahulu jika dibandingkan dengan agama Islam. Agama Hindu dan Buddha dipeluk oleh elit kerajaan, sedangkan kepercayaan asli yang bertumpu pada animisme dipeluk oleh kalangan awam. Walaupun ketiganya berbeda, tetapi semuanya bert umpu pada suat u titik. Semuanya kental dengan nuansa mistik dan berusaha mencari sangkan paraning dumadi dan mendambakan manunggaling kawula gusti.

Suatu kenyataan mistik heterodoks dan panteistik, telah mendapat tempat yang penting dalam kehidupan keagamaan Islam Jawa sejak abad ke-15 dan 16 . Hal ini bisa dibuktikan dalam karya sastra Jawa (De Graaf dan Pigeaud, 1989: 31). Meskipun masih diperdebatkan kapan Islam masuk ke Jawa, tetapi Islamisasi besar-besaran baru terjadi pada abad ke-15 (periode Gresik) dan ke16 (periode Demak) dengan momentum jatuhnya Majapahit, kerajaan Hindu Jawa pada tahun $1478 \mathrm{M}$. Dengan demikian, Islamisasi besar-besaran di Jawa terjadi justru pada saat dunia Islam pada umumnya mengalami kemunduran dalam banyak hal (Amin, 2000: 17).

Pada masa ini, Baghdad ibukota dinasti Abbasiyah, jatuh ke tangan Hulagu dan orang-orang Islam diusir dari Andalusia (Spanyol) oleh tentara Castilla dan Aragon. Selain itu, kalau pada masa-masa sebelumnya perkembangan ilmu pengetahuan dan kajian dunia Islam maju pesat dengan munculnya ulama- 
ulama besar seperti Imām Abū Ḥanīfah, Imām Mālik, Imām Syāfì'ì, dan Imām Aḥmad Ibn Ḥambal (dalam bidang fikih); Wașil ibn 'Ațā', Imām al-Asy'arī, alJubā' $\bar{i}$ dan al-Maturidì (dalam bidang teologi); al-Farābì, al- Kindì, Ibn Sinā, Ibn Miskawaih (dalam filsafat); serta al-Rāzìi, al-Mas' $\bar{u} d \bar{i}$, al-Khawarizmì, dan Hayyān (dalam bidang ilmu pengetahuan), maka sesudah tahun 1.000 terjadi penurunan di bidang pemikiran dan ilmu pengetahuan.

Kalau pada masa sebelumnya semua aspek pemikiran dapat berkembang secara berbarengan, maka pada masa ini, yang lebih berkembang adalah aspek tasawuf dengan segala aspek negatifnya. Pendekatan akomodatif menjadi lebih menonjol. Perkembangan pemikiran Islam Jawa yang lebih maju terutama dalam bidang filsafat dan tasawuf. Dengan demikian, Islam yang dibawa ke Jawa pada waktu itu adalah Islam yang berbau mistik. Adapun keutuhan umat Islam dalam politik mulai pecah dan kekuasaan khalifah mulai berkurang. Akibatnya, terjadi separatisme yang ingin memisahkan diri dari kekuasaan Baghdad (Amin, 2000: 16).

Filsafat sebagai pendukung pemikiran rasional dalam kalangan umat Islam dahulu masih dalam taraf muda. Masa itu pemikiran masih membanggabanggakan kemampuan akal manusia. Bahkan dalam masalah ketuhanan yang terlalu gaib pun ingin dicapai dengan perantara dalil akal. Pengaruh rasionalisme yang kebablasan ini sangat kental dalam ilmu kalam dan filsafat Islam. Dengan pemikiran filsafat, para filosof itu merasa mampu mencapai Tuhan bahkan tanpa perantara firman sekalipun. Petunjuk wahyu kadang-kadang dianggap hanya untuk orang awam yang tidak mampu menggapai pemikiran secara falsafi. Pendapat semacam ini terdapat dalam novel karya Ibn Ṭufayl berjudul Hayy ibn Yaqụān (Simuh, 1995: 20).

Tasawuf juga merupakan dimensi spiritual Islam yang lebih kompromis dengan budaya dan tradisi setempat, termasuk tradisi Jawa. Hal ini karena kecenderungan ajaran Sufi yang mistis sehingga banyak persamaan warna. Adanya persamaan warna, yakni mistik, meringankan tugas para muballigh yang disebut Walisongo, dalam menyiarkan dan mengajarkan Islam kepada masyarakat sehingga masyarakat cenderung lebih mudah unt uk menerimanya. Apalagi ditambah dengan watak toleran orang-orang sufi dalam menghadapi perbedaan pandangan yang berkaitan dengan tradisi dan kepercayaan lokal. Oleh karena itu, wajarlah kiranya bila mau membaca syahādatayn sudah dianggap saudara seiman dan seagama (Amin, 2000: 15).

Di Jawa, perkembangan dakwah Islam mengalami proses yang cukup unik dan berliku-liku. Hal ini disebabkan adanya kekuatan tradisi budaya dan sastra Hindu Kejawen yang mengakar dalam dan cukup kokoh yang berpusat dan 
dikembangkan menjadi sendi-sendi kehidupan politik kebudayaan kerajaankerajaan kejawen semenjak zaman jauh sebelum Islam hingga kerajaan Mataram. Kasultanan Mataram baru berakhir fungsinya sebagai pusat tradisi agung sastra budaya kejawen sesudah zaman kemerdekaan dengan beralihnya sistem pemerintahan menjadi republik (Simuh, 1995: 22).

Ditinjau dari sudut sistem keagamaan, dengan datangnya pengaruh tradisi budaya Hindu-Buddha ke Jawa, kebudayaan akhirnya berkembang menjadi dua lapis. Kebudayaan priyayi yang berpusat di istana-istana kerajaan yang diperhalus dengan unsur-unsur agama dan budaya Hindu yang membentuk tradisi besar sebagai lapisan atas dan tradisi kecil di lapisan wong cilik. Tradisi priyayi yang mampu menyerap ajaran filsafat dan sastra Hindu-Buddha berkembang amat halus dan mendalam. Tradisi budaya beserta sastra dan seni yang mendalam ini merupakan tiang tegaknya wibawa istana dan golongan priyayi sebagai kelas berdarah ningrat (Simuh, 1995: 25).

\section{Budaya dan Tradisi Jawa}

Dakwah Islam di Jawa berhadapan langsung dengan budaya dan tradisi Jawa. Oleh karena itu, untuk waktu yang relatif panjang dakwah Islam sulit dan hampir tidak masuk ke lingkaran tradisi besar pada kalangan istana. Tradisi besar sampai tahun $1478 \mathrm{M}$ saat hancurnya bingkai kerajaan Majapahit masih mengagungkan tradisi Hindu-Buddha. Dakwah Islam terpaksa harus menyusup dari lapisan bawah dan menyebar melalui budaya masa di pedesaan dan pesisiran.

Pada masyarakat bawah, kedatangan agama Islam ini disambut dengan hangat. Mereka memandang agama Islam sebagai rahmat yang membebaskan mereka dari zaman kejahiliyahan dan mengangkat derajat mereka menjadi kaum terpelajar baru yang jadi ahli agama. Sebelumnya, tradisi Hindu belum memberikan kebebasan lapisan bawah untuk belajar agama. Agama Islam yang anti kelas mendapat tanggapan yang menyenangkan dari orang-orang yang sudah lama merasa tertindas karena kelas sosial. Sebagai contoh, kitab suci agama lama tidak boleh disentuh oleh kaum Waisya dan Sudra. Yang berhak mempelajari hanyalah kaum brahmana, kelas tertinggi dalam struktur sosial.

Perkembangan Islam di pesisiran juga didukung oleh kepustakaan. Ajaran Islam dikembangkan dengan mengajarkan al-Qur'an dan al-Hadis yang tertulis dalam mushaf. Selain itu, banyak kitab syarah, kitab sejarah, kitab riwayat sahabat yang tertulis dan kisah-kisah yang diajarkan di pusat-pusat pendidikan yang kemudian berkembang menjadi bibit-bibit pesantren. Karena itulah, perkembangan Islam di nusantara didukung oleh kaya-rayanya kitab kepus- 
takaan sebagai acuan pengajaran. Sebagai kita maklumi, Gresik, Tuban, dan Jepara dahulu adalah pelabuhan-pelabuhan yang ramai dikunjungi saudagarsaudagar asing. Melalui pintu gerbang itulah Islam masuk ke pesisir Jawa Utara yang kemudian dengan berpusat di Demak penyebarannya ke daerah-daerah lain bahkan ke pulau lain semakin pesat.

Adapun yang memimpin penyebaran Islam ini adalah para wali, merekalah yang memimpin pengembangan agama Islam di seluruh Jawa, kemudian ke kepulauan lain di Indonesia. Para wali itu menjadi pemimpin di pusat-pusat pendidikan itu. Sistem pendidikan yang dikembangkan para wali itu lama-lama mengungguli sistem pendidikan istana. Apalagi para wali itu banyak yang berpengaruh karena keramat dan punya banyak kesaktian. Pada zaman itu, orang Jawa sangat mengagungkan kesaktian sebagai kekuatan untuk beladiri. Wali yang memiliki kesaktian lebih, akan memiliki pengikut yang lebih banyak. Kata wali berasal dari bahasa Arab itu artinya dekat atau kerabat, atau teman. Dalam al-Qur'an, istilah ini disebutkan yang artinya:

"Ingatlah! Sesungguhnya wali Allah, mereka tidak merasa takut dan tidak berduka cita. Mereka yang beriman dan menjaga diri".

"Allah itu pelindung orang-orang yang beriman, mereka dikeluarkannya dari kegelapan kepada cahaya yang terang" (Q.S.3:256-257).

Kata "wali" menurut istilah, ialah sebutan bagi orang-orang Islam yang dianggap keramat, mereka adalah penyebar agama Islam. Mereka dianggap manusia suci kekasih Allah, orang-orang yang sangat dekat dengan Allah, yang dikaruniai tenaga gaib, mempunyai kekuatan-kekuatan batin yang sangat berlebih, mempunyai ilmu yang sangat tinggi, sakti berjaya-kewijayaan (Zarkasi, 1987: 26). Sedangkan kata sanga menurut pendapat Adnan adalah perubahan dari kata sana yang berasal dari kata Arab "tsanä berarti sama dengan mahmū d yang terpuji. Jadi Wali Sana artinya wali-wali terpuji. Hanya saja sana bukan dengan terpuji tetapi tempat (Hadiwiyono, 1984: 35).

Pendapat yang umum mengartikan kata sanga itu memang benar-benar bilangan 9, yakni bahwa wali yang terkenal benar-benar bilangan 9. Tentang bilangan sembilan ini Tjan Toe Siem berpendapat bahwa bilangan 9 itu memang merupakan simbul bagi orang Jawa yang berasal dari pengertian 8 penjuru angin ditambah dengan pusat (Zarkasi, 1987: 24). Menguatnya pengaruh para wali membuat kekuatan tandingan yang mengimbangi wibawa istana. Apalagi pada waktu itu, kekuatan istana Majapahit semakin surut karena perang saudara yang tiada henti-hentinya. Pada runt uhnya kerajaan Hindu Majapahit membuat poros priyayi Jawa kehilangan pepundhen dan sumber kehidupan mereka. para 
cendekiawan istana waktu itu tanpa malu dan ragu berbalik mendekati poros kekuatan baru dan berguru kepada para wali Islam. Dalam Babad Tanah Jawi disebutkan seorang putra Adipati Tuban yang bernama Raden Sahid keluar dari lingkungan istana yang bercorak Hindu dan berguru kepada Sunan Bonang. Raden Sahid kemudian menjadi salah seorang Walisongo dan dikenal dengan nama Sunan Kalijaga. Nama beliau ini mungkin sekali asalnya dari perkataan Bahasa Arab qā dhì - zakā. Qādhì berarti penghulu, hakim dalam agama, sedangkan zakā berarti suci. Demikian pula Mas Karebet atau Jaka Tingkir dari Pengging berguru kepada Sunan Kudus dan akhirnya menjadi menantu Sultan Trenggana di Demak. Adapun yang mula-mula menciptakan dan menggunakan istilah Walisongo ini ialah Sunan Giri II. Ia mempergunakan dalam judul kitab karangannya dengan nama Sunan Giri II.

Wali salumahing bumi

kang kasebut ing riwayat

anenggih sewu cacahe

yekti samya kedunungan

aliya tanah-tanah

sambunging wali wolu

yekti akeh kewala

(Zarkasi, 1987: 26)

Terjemah:

Wali di atas bumi

yang disebut dalam riwayat

seribu jumlahnya

menyebar di tempatnya masing-masing

yang berbeda-beda

sebagai penerus wali delapan

yang banyak sekali

Jadi menurut Serat Wali Sana tersebut jumlah wali itu banyak sekali. Sedangkan yang terkenal hanya delapan orang saja, dan Syeh Siti Jenar tidak termasuk. Sedang yang lain disebut Wali Nukiba yang jumlahnya ribuan, terdapat di mana-mana. Arti nukiba ini mungkin perubahan ucapan kata Arab nawbah, masdar bagi fi 'il maḍi nābun, dan merupakan sinonim (murādif) bagi kata aqbah atau badal, yang artinya wakil, atau belakangan, atau pengganti (Hadiwiyono, 1984: 53). Pengertian Walisongo dapat dipahami secara denotatif maupun konotatif. Dalam pengertian denotatif nama Walisongo berarti se- 
jumlah guru besar atau ulama yang diberi tugas untuk dakwah dalam wilayah tertentu. Dalam pengertian konotatif bahwa seseorang yang mampu mengendalikan babahan hawa sanga (9 lubang pada diri manusia), maka dia akan memperoleh predikat kewalian yang mulia dan selamat dunia akhirat.

Pesantren di Jawa memiliki akar-akar budaya, ideologis, serta historis. Sebagai institusi pendidikan, pesantren, adalah wujud kesinambungan budaya Hindu-Buddha yang diislamkan secara damai. Lembaga guru cula juga ditemukan pada masa pra-Islam di Jawa. Lembaga ini pada saat Islam datang tidak dimusnahkan, melainkan dilestarikan dengan modifikasi substansi nuansa Islami. Karena itu, pesantren di Indonesia, khususnya di Jawa tergolong unik dan semakin menguat dari waktu ke waktu. Pesantren di sini berarti institusi pendidikan sebagai komunitas santri.

\section{Menggali Kearifan LoKal}

Menggali kearifan lokal amat penting dilakukan dalam rangka dakwah Islamiyah sebagaimana yang telah dicontohkan oleh para Walisongo dalam menyebarkan Islam. Bagi Walisongo, mendidik adalah tugas dan panggilan agama. Mendidik murid sama halnya dengan mendidik anak kandung sendiri. Pesan mereka dalam konteks ini adalah

"Sayangi, hormati dan jagalah anak didikmu, hargailah tingkah laku mereka sebagaimana engkau memperlakukan anak turunmu. Beri mereka makanan dan pakaian hingga mereka dapat menjalankan syariat Islam dan memegang teguh ajaran agama tanpa keraguan" (Abdul Jamil, 2000: 9).

Ajaran Walisongo tentang ketuhanan yang disampaikan kepada orang Jawa merata ke seluruh lapisan masyarakat, sebagaimana ungkapan luhur di bawah ini.

Pangeran itu siji, ana ing ngendi papan, langgeng, sing nganakake jagad iki saisine, dadi sesembahane wong sa'alam kabeh, nganggo carane dhewedhewe.

Pangeran iku ana ing ngendi papan; aneng sira uga ana Pangeran, nanging aja sira wani ngaku Pangeran.

Pangeran iku adoh tanpa wangenan, cedhak tanpa senggolan.

Pangeran iku langgeng, tan kena kinaya ngapa, sangkan paraning dumadi.

Pangeran iku bisa maujud, nanging wewujudan iku dudu Pangeran.

Pangeran iku kuwasa tanpa piranti, akarya alam saisine, kang katon lan kang ora kasat mata.

Pangeran iku ora mbedak-mbedakake kawula. 
Pangeran iku Maha Welas lan Maha Asih; hayuning bawana marga saka kanugrahaning Pangeran.

Pangeran iku Maha Kuwasa; pepesthen saka karsaning Pangeran ora ana sing bisa murungake.

(Siswoharsoyo, 1957: 25).

Terjemahan :

Tuhan itu satu, ada di mana-mana, abadi, pencipta alam seisinya, dan menjadi sesembahan manusia sejagad raya, dengan memakai tata caranya masingmasing.

Tuhan itu ada di mana-mana, juga ada pada dirimu, tapi jangan engkau berani mengaku dirimu Tuhan.

Tuhan itu jauh tanpa ada batasnya, dan dekat sekali tapi tidak dapat bersentuhan.

Tuhan itu abadi, tidak dapat digambarkan perwujudan-Nya, merupakan sebab yang pertama dan merupakan tujuan terakhir dari segala ciptaan yang ada.

Tuhan itu dapat berwujud, tapi perwujudan itu bukanlah Tuhan.

Tuhan itu berkuasa tanpa menggunakan alat apa pun; pencipta alam seisinya, baik yang tampak maupun yang tidak tampak.

Tuhan itu tidak membeda-bedakan makhluk.

Tuhan itu Maha Rahim dan Maha Kasih, dan kebahagiaan semesta ini adalah anugerah Tuhan.

Tuhan itu Maha Kuasa, tidak ada yang dapat menggagalkan kepastian atas kehendak Tuhan.

Ajaran-ajaran Walisongo tentu tidak dapat dipisahkan dari ajaran dasar Sufisme. Sufisme sebagai elemen aktif dalam penyebaran Islam di Jawa terlihat jelas dengan kehadiran tarekat Qadiriyyah, Naqsabandiyyah, Syațāriyah, serta Suhrawardiyyah yang telah berkembang dari abad ke abad. Selama ini para ilmuwan berpendapat bahwa ada koneksi tegas antara perkembangan tarekat dan pesantren di Jawa. Dua elemen ini saling memperkuat dari abad ke abad. Tarekat juga berhubungan dengan asosiasi para saudagar dan pengrajin. Para anggota tarekat di Jawa terdiri dari berbagai macam penyandang profesi. Tidak boleh dilupakan bahwa sifat tarekat Jawa yang ukhrawì dan duniawi ini juga agak mirip asosiasi yang ada pada era Hindu Jawa. Pat ut dicatat pula bahwa Ghazālian Sufism yang Asy'ari dan Syafii-oriented sangat mendominasi perkembangan Sufi di Jawa sejak awal. Nasihat Syaikh Bāri atau The Admonitions of Seh Bari, sebuah manuskrip Jawa yang agaknya ditulis oleh Sunan Bonang. 
Pendekatan-pendekatan Walisongo di kemudian hari terinstitusi dalam tradisi pesantren. Pola hidup saleh, modeling dengan mencontoh dan mengikuti para pendahulu yang terbaik, mengarifi budaya dan tradisi lokal, adalah ciri utama komunitas ini. Salah seorang putra Jaka Tingkir, Pangeran Benawa, misalnya yang hidup di awal abad ke-17 memilih tarekat sebagai jalan hidupnya. Sampai akhir hayatnya beliau menjadi seorang pemimpin tarekat. Meskipun Benawa berasal dari keluarga bangsawan, ternyata kehidupan religius spiritual lebih memikatnya hingga ia menjauhkan diri dari kehidupan politik negara. Keput usannya untuk tinggal di kota Kudus sebagai pemimpin tarekat tidak berbeda dengan keput usan pendahulunya, Sunan Kudus, yang memperkaya diri dengan kehidupan spiritual dan ilmu-ilmu agama hingga dia dikenal sebagai wali al-'ilmi pada masa kerajaan Islam Demak. Tarekat dan supremasi ilmu agama sebagaimana yang telah terukir dalam sejarah agaknya merupakan ciri lain kehidupan pesantren.

\section{E. Pendidikan Multikulturalisme}

Sikap toleran Walisongo menimbulkan dampak yang positif. Masyarakat muslim Jawa menjadi sadar arti penting pendidikan multikultural. Munculnya ritual-ritual asli Jawa yang telah diislamkan seperti upacara surtanah, nelung ndina, mitung ndina, matang puluh ndina, nyatus, mendhak, nyewu, dan sebagainya. Di bidang seni, terciptalah gubahan-gubahan wayang purwa yang bersumber dari agama dan kebudayaan Hindu. Woro Drupadi, yang dalam versi India bersuamikan lima orang anggota Pandawa (melakukan poliandri), digubah hanya bersuamikan Puntadewa, putera sulung Pandawa. Di bidang arsitektur, muncul bentuk-bentuk masjid yang berbeda dengan yang berada di kawasan dan negeri Islam lainnya.

Di bidang pendidikan, muncul pondok pesantren, yaitu suatu lembaga pendidikan yang menurut Ki Hajar Dewantara, tokoh pendidikan nasional, bercorak khas Indonesia. Apalagi ditelusuri lebih lanjut akan mendapatkan bahwa pondok pesantren adalah kelanjutan dan modifikasi dari lembaga pendidikan Hindu Mandala dengan Ki Ajar sebagai figur dan para cantrik sebagai pembantu dan muridnya. Ciri khas masjid di Jawa ialah dibangun di sebelah barat alun-alun, sebuah lapangan persegi yang ditanami rumput, dan terdapat hampir di semua kota kabupaten dan kecamatan.

Walaupun gerakan Islam Bintoro di bawah pimpinan Walisongo telah kuat dan berhasil dapat menghimpun segala kekuatan rakyat di pesisir utara, namun Walisongo tiada mau gegabah, meremehkan, apalagi menyerang dan menaklukkan Majapahit yang telah nyata bobrok dan lemah mengalami krisis dari 
dalam dan diintai ancaman dari luar. Krisis dari dalam ini yang paling berbahaya ialah gerakan yang ingin memberontak di bawah pimpinan Empu Supogati, sedang yang dari luar ialah ancaman dari raja Kaling atau Kediri bernama Prabu Girindra Wardhana. Keduanya mempunyai sejarah permusuhan sejak permusuhan Jayakatwang dengan Raden Wijaya (Zarkasi, 1987: 33).

Setelah Majapahit hancur karena kelemahannya sendiri dan serangan dari musuhnya, maka diangkatlah Raden Patah oleh Wali-wali itu menjadi Sultan Demak. Mula-mula Sunan Giri ditetapkan oleh para Wali itu sebagai "Raja Islam Sementara" dalam masa peralihan yakni selama 40 hari. Setelah itu Sunan Giri menyerahkan tahta dan menyerahkan kepada Raden Patah sebagai Raja Islam bergelar: Sultan Syah Alam Akbar, Brawijaya Sirullāh Khalifatur Rasulillah wa Amīr al-Mu'minīn Bujadi Abd al-Hāmid Haq. Sedang para Wali setelah Raja Islam dinobatkan, mereka menempati jabatan-jabatan sebagai "Pujangga" ngiras kinarya pepunden, jaksa kang nengku perdata, yaitu sebagai pujanggapujangga terhormat, jaksa perdata, sedang khusus untuk Sunan Giri menjabat sebagai "Penghulu" (Zarkasi, 1987: 43).

Raja Islam di Jawa yang pertama Raden Patah adalah tunjukan atau dipilih oleh para Wali. Dia merupakan penguasa politik, sedang para wali dengan pimpinan Sunan Giri menguasai keagamaan, keduanya merupakan kekuasaan "Dwi-Tunggal". Walaupun demikian raja harus mengugemi agama Islam dan memperjuangkan agama negara. Sebagai bukti bahwa raja harus beragama ditunjuki oleh suatu keharusan bagi raja untuk memakai baju takwa, yang diberi nama Kyai Gondil, yang kemudian dinamakan baju "Antakusuma" (anta= tiada terbatas, kusuma = bunga). Maksudnya: "sifat-sifat terpuji yang harum dan tak terbatas". Hal di atas memberi isyarat kepada seseorang bahwa raja harus dengan sungguh-sungguh memegangi Islam dan wali-wali berfungsi sebagai penunt unnya (Siswoharsoyo, 1957: 23).

Dengan demikian posisi Sunan Giri sebagai perwakilan golongan ulama dalam membina masyarakat Jawa dalam bidang politik sangat sentral. Sunan Giri selama 40 hari pertama di Kasultanan Demak meletakkan dasar-dasar kepemimpinan Islam berdasarkan al-Qur'an dan sunnah Rasul. Sunan Giri membangun struktur pemerintahan dan berbagai peraturan sebagai undangundang negara. Kemudian setelah semuanya selesai, dengan lapang dada dan tanpa nafsu ingin berkuasa, Sunan Giri melantik Raden Patah yang berdarah satria sebagai raja, pepundhen dan khalifātullāh Tanah Jawa (Kamajaya, 1990). Kelihatan sekali bahwa tanah Jawa pernah memiliki hubungan 'ulāmā' dan umāra' yang sangat ideal. Keduanya saling menghormati akan tugas dan kewajibannya masing-masing. 


\section{F. SimpUlan}

Pengajaran Islam yang dilakukan para wali beserta para 'ulāmā' dan umāra' di tanah Jawa diterima secara luas. Para bangsawan, agamawan, budayawan, dan kawula di pedesaan berbondong-bondong berguru kepada Walisongo. Para raja Jawa yang menjadi murid Walisongo di antaranya Sultan Demak, Sultan Pajang dan Sultan Mataram. Kebijakan para penguasa Jawa selalu bereferensi kepada akhlak al-karimah dan nilai kebajikan. Hubungan umara-negarawan mendapat bimbingan rohani dari ulama-agamawan.

Kemampuan Walisongo dalam bidang seni budaya berprinsip Jawa digawa Arab digarap. Wulangan, wejangan, dan wedharan beliau senantiasa berusaha menjaga keselarasan agama dan budaya. Akulturasi antara teks-teks keagamaan dengan wacana kebudayaan melahirkan kearifan lokal yang mampu menciptakan suasana harmonis dalam kehidupan masyarakat Jawa. Peralihan dari adat lama menuju kehidupan baru yang bernuansa Islam tetap berjalan secara aman, tentram dan damai, tanpa menimbulkan kegoncangan.

Berkaitan dengan ajaran budi pekerti dijelaskan pula mengenai pengendalian diri, toleransi dan sifat kemanusiaan. Semua itu memberi gambaran yang utuh dan menyeluruh tentang aspek keagamaan yang telah diwariskan oleh Para Wali Guru Suci Ing Tanah Jawi. Syariat, tarikat, hakikat, makrifat atau sembah raga, cipta, jiwa, rasa menjadi landasan utama ajaran Wali Agung ini. Ajaran hidup para wali dapat digunakan sebagai kaca benggala bagi praktik keagamaan pada era mutakhir sekarang.

\section{Daftar Pustaka}

Amin, Darori. 2000. Islam dan Kebudayaan Jawa. Yogyakarta: Gama Media. De Graaf, dan Pigeaud. 1989. Kerajaan-Kerajaan Islam di Jawa. Jakarta: Grafiti Pers.

Dwiyanto, Djoko. 2010. Penghayatan Kepercayaan terhadap Tuhan Yang Maha Esa. Yogyakarta: Pararaton.

Geertz, Clifford. 1981. Abangan, Santri, Priyayi dalam Masyarakat Jawa. Jakarta: Pustaka Jaya.

Gonda. 1925. Sanskrit in Indonesia. Den Haag: Martinus Nijhoff.

Hadiwijono, Harun. 1983. Konsepsi Tentang Manusia dalam Kebatinan Jawa. Jakarta: Sinar Harapan.

Jamil, Abdul. 2000. Islam dan Kebudayaan Jawa. Yogyakarta: Gama Media. Kamajaya. 1992. Serat Centhini Latin Jilid I-6. Yogyakarta: Yayasan Centhini. 
Ricklefs. 1995. Sejarah Indonesia Modern. Yogyakarta: Gadjah Mada University Press.

Salam, Solichin. 1977. Masjid Demak dan Penyebaran Islam. Kudus: Menara.

Simuh. 1995. Sufisme Jawa: Transformasi Tasawuf Islam ke Mistik Jawa. Yogyakarta: Bentang Budaya.

Siswoharsoyo. 1957. Serat Guna Cara Agama. Yogyakarta: Percetakan Persatuan.

Zarkasi, Effendy. 1987. Unsur Islam dalam Pewayangan. Bandung: Alma'arif. 